\title{
Atherosclerosis and the Cholesterol Theory: A Reappraisal
}

\author{
Ang Peng Wong ${ }^{1 *}$, Abdul Latiff Mohamed ${ }^{1}$, Aleksandra Niedzwiecki² \\ ${ }^{1}$ Department of Graduate Studies, Research and Commercialization, Cyberjaya University College of Medical Sciences, Cyberjaya, Malaysia \\ ${ }^{2}$ Dr. Rath Research Institute, Santa Clara, USA \\ Email: *wongangpeng@hotmail.com
}

How to cite this paper: Wong, A.P., Mohamed, A.L. and Niedzwiecki, A. (2016) Atherosclerosis and the Cholesterol Theory: A Reappraisal. World Journal of Cardiovascular Diseases, 6, 391-409.

http://dx.doi.org/10.4236/wjcd.2016.611044

Received: September 17, 2016

Accepted: November 13, 2016

Published: November 16, 2016

Copyright $\odot 2016$ by authors and Scientific Research Publishing Inc. This work is licensed under the Creative Commons Attribution International License (CC BY 4.0).

http://creativecommons.org/licenses/by/4.0/

\section{Abstract}

Atherosclerosis is the precedent to ischemic heart disease, which may lead to angina, myocardial infarct, or heart failure; or to ischemic cerebrovascular disease, which may lead to stroke. The prevailing belief underlying conventional approaches to treatment of atherosclerosis and its sequel is that a diet high in cholesterol and saturated fat is the main contributory factor, triggering cholesterol build up in the intima of the blood vessels. Over the last 60 years, the blame has shifted from fats, to saturated fats, to low-density lipoprotein (LDL), and finally to oxidized LDL (Ox-LDL). Therapy has been predominantly aimed at lowering cholesterol and control of risk factors. However, there is an alternative hypothesis about the cause of heart disease linking it to the weakening of the vascular collagen matrix at the sites of high hemodynamic stress (coronary arteries) which triggers the infiltration of lipoprotein(apo) $[\mathrm{Lp}(\mathrm{a})]$ and plaque development. Accordingly, the vascular deposition of large molecules such as $\operatorname{Lp}(\mathrm{a})$ and atherosclerosis is the result of the body's endogenous protective mechanism to reinforce the weakened artery walls. Understanding this mechanism may guide the natural prevention of this disease and form the basis for developing effective therapeutic strategies aiming at natural reversal of atherosclerosis through the reinforcement of the vascular wall structure as its primary goal. This reappraisal of atherosclerosis and the cholesterol theory looked at the historical development of the theory, and the Rath and Pauling unified theory of cardiovascular disease.

\section{Keywords}

Atherosclerosis, Low-Density Lipoprotein, Oxidized Low-Density Lipoprotein, Apolipoprotein

\section{Introduction}

Atherosclerosis is conditions where arteries become narrowed and hardened due to 
plaque buildup around the artery wall. Over time, this occlusion limits flow of oxygenrich blood to the heart. Atherosclerosis is the precedent to coronary heart disease (CHD), which may lead to angina, myocardial infarct, or heart failure; or to ischemic cerebrovascular disease, which may lead to stroke. The prevailing belief underlying conventional approaches to treatment of atherosclerosis and its sequel is that a diet high in cholesterol and saturated fat is the main contributory factor, triggering cholesterol build up in the intima of the blood vessels.

The cholesterol theory in relation to atherosclerosis, or more specifically referred to as the lipid hypothesis, postulates that hypercholesterolemia is a major causative factor, or determining factor, in atherosclerosis and CHD; and correcting it will significantly reduce the burden of disease and its clinical consequences [1]. The hypothesis relates to serum lipids, and not dietary lipids. In the open debate over the last few decades on the role of cholesterol and CHD, the line between serum lipids and dietary lipids is narrow, and the two often merged. This is due to the understanding that consuming high dietary lipids will raise the cholesterol level in the blood. For over half a century, the World Health Organization (WHO) and most countries in the world have been advising a low fat diet. Two other hypotheses emerged in search for a pathogenesis of atherosclerosis, namely the respond-to-injury hypothesis [2], and the monoclonal hypothesis [3]. However, for both these hypotheses the mechanism leading to the disease is not well explained.

Based on epidemiological evidence at the time, the USA and UK in 1977 and 1983 respectively, issued dietary fat guideline focusing on reducing dietary fat intake to address the incidence of CHD. A recent published systematic review and meta-analysis study showed that the dietary fat guideline issued by the two countries was not based on evidence from randomized controlled trials (RCTs) [4]. There was RCTs evidence available at the time that showed no significant relationship between dietary interventions and CHD and all-cause mortality. The dietary committees of both countries did not consider that evidence.

Considering that heart disease has been the global leading cause of death the last twenty-five years, and will still be by 2030 [5], a few pertinent questions need be asked:

1) Could we possibly have gone wrong on the lipid hypothesis of atherosclerosis?

2) If so, at what stage of theoretical development have we faulted?

3) Is there any viable alternative to the lipid hypothesis?

This reappraisal of atherosclerosis and the cholesterol theory looked at the historical development of the theory, and the Rath and Pauling unified theory of cardiovascular disease, to attempt to answer the questions above.

\section{Background}

\subsection{Early Discovery of Cholesterol}

The lipid hypothesis of atherosclerosis has its beginning in 1913 when a young Russian experimental pathologist, Nikolai N. Anichkov, showed that feeding rabbits purified cholesterol dissolved in sunflower oil induced vascular lesions [6]. But it was Felix 
Marchand who first introduced the term "atherosclerosis" in 1904 [7]. Anichkov's study on atherosclerosis was largely unknown in the west. The first publication of Anichkov's theory of atherosclerosis in English medical literature was in Cowdry's Arteriosclerosis [8]. In 1950, when Dr. John Gofman published his paper in Science [9] and cited Anichkov's work, Anichkov began to receive worldwide recognition. Gofman and associates used an ultra-centrifugal device that, at a rotor speed of 52,640 rpm could separate cholesterol basically into two types, low-density lipoprotein and highdensity lipoprotein. Gofman went on to initiate multicenter study of lipoproteins in human plasma and made correlations with atherosclerosis. From then on there was a flood of studies on lipoproteins in relation to atherosclerosis. These studies mainly concentrated on LDL in blood vessel tissues.

Smith and Slater [10] measured LDL in arterial walls and compared these with serum cholesterol levels to show a close relation between LDL cholesterol and atherosclerosis. A subsequent study [11] confirmed the findings of Smith and Slater [10]. The association between cholesterol and atherosclerosis has been firmly established, and LDL is widely perceived as the causative factor. However, with the mechanism of how the cholesterol molecules get into the walls of blood vessels still unknown, skepticism is inevitable.

\subsection{From LDL to Oxidized LDL (OxLDL) Hypothesis}

The study of familial hypercholesterolemia led Goldstein and Brown to elucidate that the cellular uptake of LDL requires the LDL receptor [12]. Their discovery of the LDL receptor, and later their discovery of the scavenger receptor in macrophage, helped contribute significantly to the lipid theory of atherosclerosis. In 1979 Goldstein and Brown, and their associates, pursued the study of macrophages and LDL. The finding was that macrophages in culture take up and degrade LDL, and that the macrophagederived foam cells accumulate in the artery walls [13]. Another laboratory study [14] took this further discovering that LDL incubated overnight with cultured endothelial cells was converted to a form. Henriksen et al. suggested that LDL modification in endothelium permits LDL uptake and foam cell formation. Follow up studies by others showed that LDL was undergoing oxidative modification during its incubation with endothelial cells [15] [16]. Hence, the beginning of the oxidative modification hypothesis of atherosclerosis, and from thenceforth thousands of studies on atherosclerosis were conducted.

\subsection{Early Epidemiological Studies}

The "lipid theory" or the "fat causes atherosclerosis" theory was developed largely through epidemiological studies. In the 1950's Ancel Keys postulated that fat causes heart disease. It started in 1951 when Keys observed the diet of the people of Naples, Italy, whose diet was low in meat and high in vegetables, and had low rate of CHD [17]. Keys' thesis was the result of his study of the selection of six countries from which he drew correlation between mortality from CHD and fat consumption [18]. In another 
study several years later, called the "Seven Countries" study, Keys redefined the fat dietary intake association with CHD, to saturated fat [19]. From then on the blame was on saturated fat and not just any fat.

Atherosclerosis was originally considered to be an ongoing process and a normal part of aging [20]. This perception was checked when a necropsy study was conducted on soldiers killed during the Korean War [21]. In this observational study, Enos and the group [21] described coronary lesions from the autopsies of 300 male soldiers, with a mean age of 22 years, and observed that $77 \%$ had coronary disease. The Korean War study was later corroborated by the Vietnam War study [22]. McNamara et al studied 105 decedents of Vietnam War, with mean age of 22 years, and reported that $45 \%$ had coronary disease. Both these autopsy studies have demonstrated that coronary disease begins at a much younger age and is not necessarily only prevalent in the aged.

This review attempted to make a critical appraisal of studies from 1950 to 2015. (Table 1) The search methodology for atherosclerosis and the cholesterol theory in literature published in English language was conducted through the Cochrane Library,

Table 1. Evolution of the lipid theory of heart disease.

\begin{tabular}{|c|c|c|c|}
\hline Year & Discoverer/Scientist & Event/Occurrence & Comment \\
\hline 1913 & Nicholai Anichkov & $\begin{array}{l}\text { Observed vascular lesions in rabbits } \\
\text { fed with purified cholesterol } \\
\text { dissolved in Sunflower oil. }\end{array}$ & $\begin{array}{l}\text { This observation was } \\
\text { unknown to the } \\
\text { West until } 1933 \text {. }\end{array}$ \\
\hline 1950 & John Gofman & $\begin{array}{l}\text { Segregation of low and high-density } \\
\text { lipoproteins using centrifugal device. }\end{array}$ & \\
\hline $1950 \mathrm{~s}$ & John Gofman & $\begin{array}{l}\text { Multicenter study of lipoprotein } \\
\text { in human plasma. }\end{array}$ & $\begin{array}{l}\text { Correlation made between } \\
\text { cholesterol and } \\
\text { atherosclerosis. }\end{array}$ \\
\hline 1972 & Smith \& Slater & $\begin{array}{l}\text { Measured LDL in artery walls } \\
\text { and compared with serum } \\
\text { cholesterol levels. }\end{array}$ & $\begin{array}{l}\text { Association between } \\
\text { LDL cholesterol and } \\
\text { atherosclerosis. }\end{array}$ \\
\hline 1979 & Goldstein et al. & $\begin{array}{l}\text { Discovery of receptor site for LDL } \\
\text { and binding site on macrophages } \\
\text { leading to degradation of LDL. }\end{array}$ & $\begin{array}{l}\text { Helped reinforce the lipid } \\
\text { theory of atherosclerosis. }\end{array}$ \\
\hline 1981 & Henriksen et al. & $\begin{array}{l}\text { Postulated that changes in the } \\
\text { endothelium allows LDL uptake } \\
\text { and foam cells formation. }\end{array}$ & $\begin{array}{l}\text { Hypothesis of the oxidative } \\
\text { modification of LDL. }\end{array}$ \\
\hline 1983,1984 & $\begin{array}{c}\text { Hessler et al:; } \\
\text { Steinbreecher et al. }\end{array}$ & $\begin{array}{l}\text { Cell culture and in vitro studies } \\
\text { confirmed LDL undergoing } \\
\text { oxidative modification in } \\
\text { endothelial cells. }\end{array}$ & $\begin{array}{l}\text { Confirmed the hypothesis } \\
\text { and hence the beginning } \\
\text { of the OxLDL theory of } \\
\text { atherosclerosis. }\end{array}$ \\
\hline 1987 & & $\begin{array}{l}\text { FDA approved the registration } \\
\text { of statin. }\end{array}$ & $\begin{array}{l}\text { Statins work by inhibiting } \\
\text { the HMG CoA reductase } \\
\text { production in the liver. }\end{array}$ \\
\hline
\end{tabular}


MEDLINE, PUBMED, EMBASE, Science Direct, Scopus, Google, and Google Scholar databases. The following key words, in different combinations, were used: atherosclerosis, lipid theory, cholesterol theory, lipoprotein, lipoprotein (apo), oxidized low-density lipoprotein, vitamin $\mathrm{C}$, receptor site, animal studies, and clinical studies.

\subsection{The Risk Factor Paradigm of CHD}

In the absence of any interventional, randomized, controlled trial, the cause of CHD cannot be conclusively determined. So far, the body of evidence accumulated from animal models and epidemiological studies that set out to test the lipid hypothesis have been predominantly observational. The lipid hypothesis proposed that hypercholesterolemia was a causative factor in human atherosclerosis. It did not propose that hypercholesterolemia was the only cause but that it was at least a quantitatively significant factor [1]. The observational studies identified risk factors associated with CHD. Risk factors significantly associated with CHD are smoking, blood lipids, hypertension, diabetes, abdominal obesity, psychosocial factors, fruit and vegetable consumption, alcohol consumption and physical activity [23]. Treatment of CHD has been based on lowering the risk factors. To this date, it has been the established paradigm for the treatment of CHD.

\section{Description}

\subsection{Clinical Trials with Antioxidants}

The accumulated evidence that oxidative modification of LDL plays an important role in the pathogenesis of atherosclerosis in animal models is very strong [24]. The evidence arises mostly from cell culture and in vitro settings. Until and unless the OxLDL effect of atherosclerosis is evaluated in live animals, the findings remain suggestive. Without an understanding of the primary cause of atherosclerosis, the therapeutic approach of lowering the risk factors is not specific. Even the overall result of the 1984 Coronary Primary Prevention Trial using the drug, Cholestyramine, though statistically significant, was not totally convincing [25].

Over the last fifteen years, several clinical trials have set out to investigate the OxLDL hypothesis of atherosclerosis using antioxidants. The antioxidants used were mainly either vitamin $\mathrm{E}$ or beta-carotene. The results have been mixed. There are studies that show antioxidants have no positive effect [26] [27] [28]. A meta-analysis of seven randomized trials of vitamin E treatment and eight of beta-carotene treatment also show that antioxidants do not provide benefit [29]. On the other hand, there are also studies that show beneficial effect of antioxidants on atherosclerosis [30] [31] [32] [33]. These studies differ in their designs with regards to the type of nutrient, dosage, single or two nutrients combination, natural or synthetic form, length of study, study end points, subject population and age group, and the chronicity of the disease (whether pre or post myocardial infarction). In large-scale clinical trials, it is difficult to replicate the exact study design. Therefore, such variation, diverse, and even contradictory results in the studies mentioned above, is quite understandable. 


\subsection{The Vitamin C-Heart Disease Connection}

At the time when the study of atherosclerosis was much dependent on autopsy, and when conventional explanation of heart disease was that lipids or cholesterol build up on the surface of arterial walls, Canadian pathologist, J.C. Paterson was studying atherosclerosis and intimal capillary rupture leading to stroke. He suggested that the factors responsible for the rupture of intimal capillaries in the cerebral arteries are intra-capillary pressure from hypertension, degeneration of tissues, and increased capillary fragility due to advancing age and vitamin deficiency [34]. A follow up study by Paterson was conducted on coronary occlusion using microscopic examinations on plaques. It led him to conclude that hypertension is a major factor for intimal capillary bleeding and plaque formation; that capillary fragility may be due to vitamin $\mathrm{C}$ deficiency; and that calcification of atherosclerotic plaques may protect against intimal hemorrhages and coronary thrombosis [35].

The observational studies of Paterson were followed-up by another Canadian, Dr. G.C. Willis. He conducted an experimental study on guinea pigs and confirmed Paterson's suggestion that atherosclerosis is linked to vitamin C deficiency [36]. Willis also pointed out that the mechanical stress exerted onto the walls of arteries is important in the location of atherosclerosis. This mechanical stress is influenced by blood pressure, surrounding tissue pressure, radius of lumen, curvature of artery, and arterial fixation. In a later study, Willis [37] showed that vitamin C could reverse atherosclerosis in guinea pigs. In 1954, Willis conducted a controlled clinical study on the development of atherosclerosis in humans examining the femoral and popliteal arteries. Those in the treated group were given $500 \mathrm{mg}$ of vitamin C orally, three times a day, a total of 1500 $\mathrm{mg}$ a day. This preliminary serial angiography study showed that vitamin $\mathrm{C}$ could reduce atherosclerotic plaques in humans [38]. It was the first time that the evolution of atheromatous plaques had been observed over a period of time. In contrast to previous assumptions, atherosclerosis is not a slow and inevitable progressive disease. Willis' serial angiographic study showed that plaques might enlarge or become smaller fairly quickly. The study also showed that sclerotic build up is not evenly distributed throughout the blood vessels, but at specific points where the mechanical stress exerted most onto the blood vessels.

In 1971, a British pathologist, Dr. Constance Spittle, conducted a study on healthy individuals and patients with atherosclerosis using vitamin C. In healthy people under 25 years, cholesterol levels tended to fall when $1000 \mathrm{mg}$ of vitamin $\mathrm{C}$ daily was added to a normal diet whereas, in patients with a history of atherosclerosis, the serum cholesterol increased in the weeks when vitamin $\mathrm{C}$ was given. It was suggested that the transitory rise in serum cholesterol is caused by the mobilization from the artery walls [39].

HMG-CoA reductase is the enzyme in the pathway for cholesterol biosynthesis in the liver. This is the enzyme inhibited by statins [25]. In the early 1980s, among the pharmaceutical companies, there was a strong quest to produce the first drug that could inhibit cholesterol biosynthesis. Merck took the lead and its lovastatin (Mevacor) has shown promising results in lowering serum cholesterol. It was not until 1987 that the 
FDA approved lovastatin as a cholesterol-lowering drug. During the same period, Holloway, Peterson, Prigge, and Gebhard [40] observed that cholesterol synthesis in the liver of guinea pigs was reduced when fed with a diet high in vitamin C. The decreased cholesterol synthesis was also associated with the decrease in the fraction of active HMG-CoA reductase. In 1985 Greene, Harwood and Stacpoole followed up on the observation of Holloway et al. to examine the mechanism of inhibition of HMG-CoA reductase activity by vitamin $\mathrm{C}$ in guinea pig liver [41]. Their study showed that vitamin $\mathrm{C}$ has an effect on the reductase activity and cholesterol genesis. Greene and colleagues followed up on their own study and advanced from animal model studies to the study of cultured human liver cells and mononuclear leukocytes. The findings were that low-level vitamin $\mathrm{C}$ triggers the enzyme HMG-CoA reductase to catalyse the synthesis of cholesterol, and inversely, high-level vitamin $\mathrm{C}$ inhibits the enzyme activity and lowers the rate of cholesterol production [42].

There is now evidential data from observational studies, animal model studies, and laboratory studies on human cells linking vitamin $\mathrm{C}$ to the lowering of cholesterol, and that vitamin C acts as a "natural statin" (Table 2). Naturally there would be high expectations in extrapolation to humans and the pressing need to carry out pilot studies and clinical trials to investigate the effect of high dose vitamin $\mathrm{C}$ on CHD.

\subsection{Lipoprotein(a) and CHD}

There are five different types of cholesterol, namely: low-density lipoprotein (LDL), very low-density lipoprotein (VLDL), high-density lipoprotein (HDL), triglycerides, and lipoprotein(a) $[\mathrm{Lp}(\mathrm{a})]$. For many years $\mathrm{Lp}(\mathrm{a})$ in human plasma was considered a variant of LDL and attracted little interest for clinicians [43]. In CVD and CHD, much focus has been on the role of LDL. Lp(a) was discovered by Blumberg, Bernanke, and Allison [44] and by Berg [45]. Lp(a) and LDL share the same lipid and apoprotein composition, particularly apoprotein B-100 (apo B). But Lp(a) differs from LDL in that it has an additional glycoprotein, designated as apoprotein(a) [apo(a)]. In addition, $\mathrm{Lp}$ (a) has lysine-binding properties [46]. The level of $\mathrm{Lp}(\mathrm{a})$ in circulation depends primarily on its synthesis and, unlike LDL, is not determined by the efficacy of particle clearance [47]. Despite much progress made in understanding this lipoprotein particle, both the physiological role and the pathological mechanism of $\mathrm{Lp}(\mathrm{a})$ remain unclear [46].

In 1987, the discovery of the structural homology between the two proteins, apo(a) and plasminogen [48] [49], and their DNA sequence [50] led to much interest in the research of $\mathrm{Lp}(\mathrm{a})$. The significance is that plasminogen is a key protein in the process of coagulation and blood clotting. Prior to 1987, a series of epidemiological studies demonstrated positive correlation of high serum Lp(a) with CHD [51] [52] [53]. Even though apo(a) was detected in the arterial wall in 1974 [54], it was not believed to participate in atherosclerosis. The focus then was on LDL, especially after the observation of Smith and Slater (1972), the close relationship between serum lipid levels and LDL and in the intima of aorta. 
Table 2. Chronology of the vitamin C-heart disease connection concept.

\begin{tabular}{|c|c|c|c|}
\hline Year & Discovery/Scientist & Event/Occurrence & Comment \\
\hline 1940 & JC Paterson & $\begin{array}{l}\text { Studied atherosclerosis and } \\
\text { intimal capillary rupture } \\
\text { leading to stroke. }\end{array}$ & $\begin{array}{l}\text { Postulated that rupture of intimal } \\
\text { capillaries were due to pressure } \\
\text { from hypertension, degeneration } \\
\text { of tissues, and vitamin deficiency. }\end{array}$ \\
\hline 1941 & JC Paterson & $\begin{array}{l}\text { Follow up study on coronary } \\
\text { occlusion using microscopic } \\
\text { examination of plaques. }\end{array}$ & $\begin{array}{l}\text { Postulated that hypertension was } \\
\text { a main factor for intimal capillary } \\
\text { bleeding and plaque formation; } \\
\text { and capillary fragility may be } \\
\text { due to vitamin C deficiency. }\end{array}$ \\
\hline 1953 & GC Willis & $\begin{array}{l}\text { Conducted experimental study } \\
\text { on guinea pigs. Confirmed that } \\
\text { atherosclerosis is linked to } \\
\text { vitamin C deficiency. }\end{array}$ & $\begin{array}{l}\text { The mechanical stress exerted onto } \\
\text { the walls of arteries is link to the } \\
\text { location of the atherosclerosis. }\end{array}$ \\
\hline 1954 & GC Willis & $\begin{array}{l}\text { Serial angiography studies } \\
\text { showed vitamin } \mathrm{C} \text { could } \\
\text { reduce atherosclerotic } \\
\text { plaques in humans. }\end{array}$ & $\begin{array}{l}\text { Contrary to common assumption, } \\
\text { plaques could build up or be } \\
\text { reversed fairly quickly. Plaques } \\
\text { build up at points of mechanical } \\
\text { stress in blood vessels. }\end{array}$ \\
\hline 1957 & GC Willis & $\begin{array}{l}\text { Further studies showed that } \\
\text { vitamin } C \text { could reverse } \\
\text { atherosclerosis in guinea pigs. }\end{array}$ & \\
\hline 1971 & Constance Spittle & $\begin{array}{l}\text { Studied the effect of vitamin C } \\
\text { on healthy individuals and } \\
\text { patients with atherosclerosis. }\end{array}$ & $\begin{array}{l}\text { The transitory rise in serum } \\
\text { cholesterol could be due to } \\
\text { uprooting of cholesterol } \\
\text { from the blood vessels. }\end{array}$ \\
\hline 1981 & Holloway et al. & $\begin{array}{l}\text { Observed that guinea pigs fed with a } \\
\text { diet high in vitamin C could reduce } \\
\text { cholesterol synthesis in the liver. }\end{array}$ & $\begin{array}{l}\text { Simultaneously HMG CoA } \\
\text { reductase was reduced. }\end{array}$ \\
\hline 1985 & Green et al. & $\begin{array}{l}\text { Studied the mechanism of vitamin C } \\
\text { inhibition of HMG CoA reductase } \\
\text { activity in guinea pig liver. }\end{array}$ & $\begin{array}{l}\text { Study showed that vitamin } \mathrm{C} \text { has } \\
\text { an effect on reductase activity } \\
\text { and cholesterol genesis. }\end{array}$ \\
\hline 1986 & Harwood et al. & $\begin{array}{l}\text { Advanced from animal model } \\
\text { study to the study of human } \\
\text { liver cells culture. }\end{array}$ & $\begin{array}{l}\text { Low-level vitamin C triggered the } \\
\text { HMG CoA reductase to catabolize } \\
\text { cholesterol. High-level vitamin C } \\
\text { reversed the effect. }\end{array}$ \\
\hline
\end{tabular}

The inverse relationship of $\mathrm{Lp}(\mathrm{a})$ to vitamin $\mathrm{C}$, and the observations that $\mathrm{Lp}(\mathrm{a}) \mathrm{mo-}$ lecules are primarily found in humans and in a few animal species (primates and fruit bats), led Matthias Rath, a German physician, to study vitamins and heart disease [55]. Rath also observed that animals that are able to produce optimum amounts of vitamin $\mathrm{C}$ do not need Lp(a) in any significant amount. Most animals have predominantly the four types of cholesterol and lipid carrying vehicles: LDL, VLDL, HDL, and triglyce- 
rides. Humans and animals that do not synthesize vitamin $\mathrm{C}$ endogenously have the additional $\mathrm{Lp}(\mathrm{a})$.

Rath and his German colleagues first set out to investigate the possible accumulation of apo(a) in the arterial wall in relation to serum $\mathrm{Lp}$ (a) concentrations, and to compare the relationship between serum arterial wall apo B (protein component of LDL), in fresh arterial wall tissues [56]. This cohort observational study showed significant positive correlation between serum $\mathrm{Lp}(\mathrm{a})$ and arterial wall apo(a). High serum $\mathrm{Lp}(\mathrm{a})$ also led to a significant increase of apo B in the arterial wall, but no significant correlation was found between apo B in serum and aortic tissue. Both apo(a) and apo B were found to be co-located in the arterial wall, predominantly located extracellularly. This study shows that $\mathrm{Lp}(\mathrm{a})$ accumulates in the arterial wall thereby contributing to plaque formation and CHD. A follow up study on autopsy tissues of aorta and left coronary artery (n = 74) confirmed the location of apo(a) in arterial intima, predominantly at the extracellular matrix [57]. Since apo(a) is a component of $\operatorname{Lp}(a)$, it was suggested, for the first time, that $\mathrm{Lp}(\mathrm{a})$ is an atherogenic particle. This differs from the finding of Smith and Slater [10] as did findings of Rath et al. [56]. Apo(a) remains intact and stays in the arterial intima for years without breaking down. If it had been LDL it would have been taken up by macrophages to form foam cells, thus resulting in the presence of fatty streaks at cell walls. Rath and colleagues presented a strong case for the $\mathrm{Lp}(\mathrm{a})$ as an independent risk factor for CHD. The mechanism leading to the accumulation of $L p(a)$ in the arterial wall is still not explained.

The study of Beisiegel, Niendorf [58] confirmed that Lp(a) contributes to plaque development by extracellular accumulation and only its minor amount is taken up in foam cells. More importantly this study suggested the mechanism that apo(a) might bind to fibrin and thereby inhibit the action of plasminogen. Apo(a) and fibrin are co-localized in the arterial wall and in the presence of $\mathrm{Lp}(\mathrm{a})$ will eventually become part of the plaque. $\mathrm{Lp}(\mathrm{a})$ can bind to the plasminogen receptor of endothelial cells [59] and enters the arterial intima via this pathway.

\subsection{The Vitamin C-Heart Disease Connection: A New Concept}

The combined team of Matthias Rath and Linus Pauling in 1990 developed the research on CHD much further. This begins with their hypothesis that $\mathrm{Lp}(\mathrm{a})$ is a surrogate for vitamin C [60]. The main reason for this hypothesis is that $\mathrm{Lp}(\mathrm{a})$ is found generally in the blood of primates and guinea pig, but rarely in the blood of other animals. Interestingly, primates and guinea pigs have lost the ability to synthesize vitamin $\mathrm{C}$. The other reasons are that $\mathrm{Lp}(\mathrm{a})$ and vitamin $\mathrm{C}$ share the same properties of accelerating wound healing and cell repair mechanisms, strengthening of extracellular matrix such as the walls of blood vessels, and the prevention of lipid peroxidation. At that point in time, it was known that $\operatorname{Lp}(\mathrm{a})$ is an extremely atherogenic lipoprotein. The mechanism by which it exerts its atherogenicity is still not fully understood. Lp(a) has been found in humans and primates. Rath and Pauling postulated that the guinea pigs would be found to produce $\operatorname{Lp}(\mathrm{a})$. To test this hypothesis, Rath and Pauling conducted an experimental 
study on guinea pigs by inducing atherosclerosis through dietary vitamin $\mathrm{C}$ depletion [61]. This study produced two crucial findings. Firstly, that a reduction of dietary vita$\min \mathrm{C}$ is sufficient to cause atherosclerotic plaques. Secondly, the immunological evidence for an accumulation of apo(a) in the atherosclerotic plaque of the hypoascorbemic guinea pig. Hence, based on the findings of Rath, Niendorf [56], Lp(a) is present in the atherosclerotic lesion and that $\mathrm{Lp}(\mathrm{a})$ contributes to plaque formation in this animal model study. An important finding of this study is that appropriate amounts of vitamin C prevent the development of atherosclerosis and the deposition of $\operatorname{Lp}(\mathrm{a})$ in the arterial wall.

Rath and Pauling presented a new concept of pathological mechanism for CVD. CVD is primarily a degenerative disease and the primary cause is a deficiency in vitamin $C$ which triggers impaired collagen synthesis thereby leading to the deposition of $\mathrm{Lp}$ (a) and fibrinogen/fibrin in the arterial wall [62] to compensate for its structural weakness. Rath and Pauling's new concept of pathological mechanism differs from those of Brown and Goldstein [63], Ross [64], and Steinberg, Parthasarathy [65]. It is also a wonder why Fortmann and Marcovina [46] did not consider Rath and Pauling's new concept which was published in 1991.

Rath and Pauling's pathological mechanism for CVD was extended further when they observed that apo(a) contains an amino acid sequence: arginine-glycine-aspartate (RGD) tripeptide, a characteristic sequence in adhesive proteins. RGD interacts with integrins, a family of cell receptors for adhesive proteins [66]. Rath and Pauling [67] suggested that apo(a) is an adhesive protein and physiologically it mediates cell adhesion and migration, as well as processes like cell differentiation and growth. Under pathological conditions, apo(a) which is a large protein comparable in size to collagen can compensate for vitamin $\mathrm{C}$ deficiency. When the collagen matrix is weak, apo(a) mediates in cellular and extracellular chronic repair processes. Apo(a) is involved in tissue repair processes such as would healing [68].

In 1992, Rath and Pauling presented a unified theory of CVD [69] when at that time the therapeutic concepts for CVD were targeting specific risk factors or individual pathological mechanism. The theory is that vitamin C deficiency is an important underlying factor and that all mechanisms leading to CVD can be triggered by vitamin C deficiency. The study of the pathological mechanism in CVD led Rath to advance the concept further. He recognized that most chronic diseases proliferate via a similar pathological mechanism, and the most commonly held view is the one propagated by oxygen free radicals. Rath and Pauling [70] proposed another pathological mechanism: the enzymatic degradation of the connective tissue by the protease, plasmin. In healthy physiological condition, plasmin-induced proteolysis assists in cell migration and organ remodeling. But in pathological condition, this mechanism becomes aggravated leading to excessive degradation of the extracellular matrix. Rath and Pauling had earlier proposed that apo(a) functions as an endogenous inhibitor of plasmin-induced proteolysis [67]. They further proposed that exogenous inhibitors of plasmin-induced proteolysis include L-lysine and synthetic lysine analog, tranexamic acid. With these postulations, 
pilot studies and clinical trials might have been expected from the scientific field.

Extra cellular matrix (ECM) plays an important role in maintaining optimum elasticity and integrity of the arterial walls. The ECM undergoes significant changes during atherosclerotic process, which include an increase in the endothelial gaps facilitating increased migration of blood borne-leucocytes and excessive degradation of ECM proteins, migration, and proliferation of smooth muscle cells, neovascularization, and cell apoptosis among others. The natural compounds such as vitamin $\mathrm{C}$ are important in maintaining optimum vascular functions by affecting synthesis and deposition of Collagen IV in the basement membrane, collagen I, scavenging of free radical species, and sparing endothelial cell derived nitric oxide to help modulate blood flow.

Prolonged deficiency of ascorbic acid, a nutrient not produced in the human body, hinders enzymatic hydroxylation of proline and lysine residues in collagen molecules, thereby impairing the stability of the vascular wall. Thus, combined supplementation with ascorbic acid and lysine has been proposed as a preventive measure to atherosclerosis development [Rath M: Solution to the puzzle of human cardiovascular disease: its primary cause is ascorbate deficiency, leading to the deposition of lipoprotein(a) and fibrinogen/fibrin in the vascular wall [71]. Study using a mouse model, which is unable to produce endogenous vitamin C (Gulo-/-) have demonstrated structural changes in the vascular wall accompanied by elevated cholesterol levels triggered by ascorbate deficient diet [72]. In vitro study with vascular smooth muscle cells isolated from guinea-pig aorta investigated the direct and matrix-mediated effects of ascorbate on the proliferation rate of these cells. The results showed diminished cell proliferation in the presence of $0.5-2 \mathrm{mM}$ ascorbate, in a dose-dependent manner without cytotoxic effect [73].

Additionally, a number of studies showed cardio-protective effects of other micronutrients, such as those contained in tea, through their potent antioxidant activity [74] Also, vitamin C, amino acid, lysine and proline, green tea extract, and quercetin, among others have shown to strengthen the integrity of ECM. Ivanov et al., have reported that a mixture of ascorbic acid, quercetin, green tea extract and gotu kola effectively reduce monocyte binding to the ECM thereby reducing atherosclerotic plaque buildup [75].

\subsection{Vitamins and CHD: Clinical Implications}

In a pilot clinical study involving patients with elevated plasma $\mathrm{Lp}(\mathrm{a})$ levels, vitamin $\mathrm{C}$ was found to lower its levels in 9 out 11 patients on average by $27 \%$, with a median value also of $27 \%$ [76]. On the basis of an improved understanding on the pathogenesis of CVD, Rath proceeded to define a new therapeutic approach for reducing the risk of CVD with nutritional supplements. The basis for this approach is that vitamin C is essential for restoring and preserving the integrity and stability of the vascular wall. Niacin and vitamin $\mathrm{C}$ were reported to lower $\mathrm{Lp}(\mathrm{a})$ levels. L-lysine and L-proline compete and interfere with the binding of $\operatorname{Lp}(\mathrm{a})$ to the vascular wall and atherosclerotic lesion, and prevent further build up of $\operatorname{Lp}(\mathrm{a})$ in the vascular wall. Both amino acids could facilitate a release of deposited $\mathrm{Lp}(\mathrm{a})$ and also other atherogenic lipoproteins from the vas- 
cular wall. The therapeutic implication is the non-invasive reversal of existing CVD with nutritional supplements [72].

Following this, Rath and Niedzwiecki [76] conducted a clinical trial to determine the effect of a defined nutritional supplement program on the natural progression of coronary artery disease. This nutritional supplement program was comprised of vitamins, amino acids, minerals and trace minerals, and other essential nutrients. Overall, this prospective interventional controlled trial shows the reduction of the progression of coronary artery calcification by an average of $15 \%$ and documents a natural reversal of early atherosclerotic deposits in individual patients.

\subsection{Vitamin C Affects Lp(a) in Transgenic Mice}

Animal model studies for CVD over the last few decades were faced with the problem of close representation of human physiology. Humans do not synthesize vitamin C, but are able to synthesize $\mathrm{Lp}(\mathrm{a})$. This is due to genetic loss of gulono-lacto-oxidase (GLO) in the ancestor of man about 40 million years ago. This enzyme is necessary in the process of vitamin C synthesis. Over the last five years scientists of the Dr. Rath Research Institute, through cross breeding and genetic modification, successfully developed a transgenic specie of mice which is not being able to synthesize vitamin $\mathrm{C}$ and at the same time is able to produce human $\operatorname{Lp}(\mathrm{a})$ in the liver. These transgenic mice mimic human metabolism and pathophysiology in key respects: a loss of endogenous vitamin $\mathrm{C}$ synthesis and the production of $\operatorname{Lp}(\mathrm{a})$. In the research published recently in the American Journal of Cardiovascular Disease [77], the transgenic mice were divided into three dietary groups: deprived of vitamin $\mathrm{C}$ and receiving low and high dosage of vitamin $C$ daily. When given a diet containing insufficient amount of vitamin $C$, the mice were found to deposit $\mathrm{Lp}(\mathrm{a})$ in their vascular walls and develop atherosclerosis. The degree of the lesion was found to be inversely related to their intake of vitamin C. Figure 1 and Figure 2 (adopted with permission) from this publication illustrate this phenomenon. The size of atherosclerotic plaque correlated with $\mathrm{Lp}(\mathrm{a})$ and not the amount of cholesterol. A complete absence of dietary vitamin C intake resulted in a significant increase in serum Lp(a) levels in mice. This was also accompanied by increased accumulation of the $\mathrm{Lp}(\mathrm{a})$ in the arteries at the site of highest mechanical stress near the heart, and leading to plaque deposition. Mice with the highest intake of vitamin $\mathrm{C}$ had the lowest deposition of $\operatorname{Lp}(\mathrm{a})$ in their arteries. This latest study by the scientists of the Dr. Rath Research Institute suggests that CHD is an early form of the vitamin C deficiency disease, scurvy leading to vascular deposition of $L p(a)$. The results confirm the scientific concepts of Dr. Matthias Rath in the 1990's [67] [69] [70] [71] [72] [73], that Lp(a) can function as a repair molecule accumulating at the sites of vessel wall damage (insufficient collagen production) during vitamin $\mathrm{C}$ deficiency.

\subsection{Implications of Vitamin C-Lp(a)-CHD Connection}

Currently accepted cholesterol-based theory of heart disease is not able to adequately answer the key questions in cardiology. 


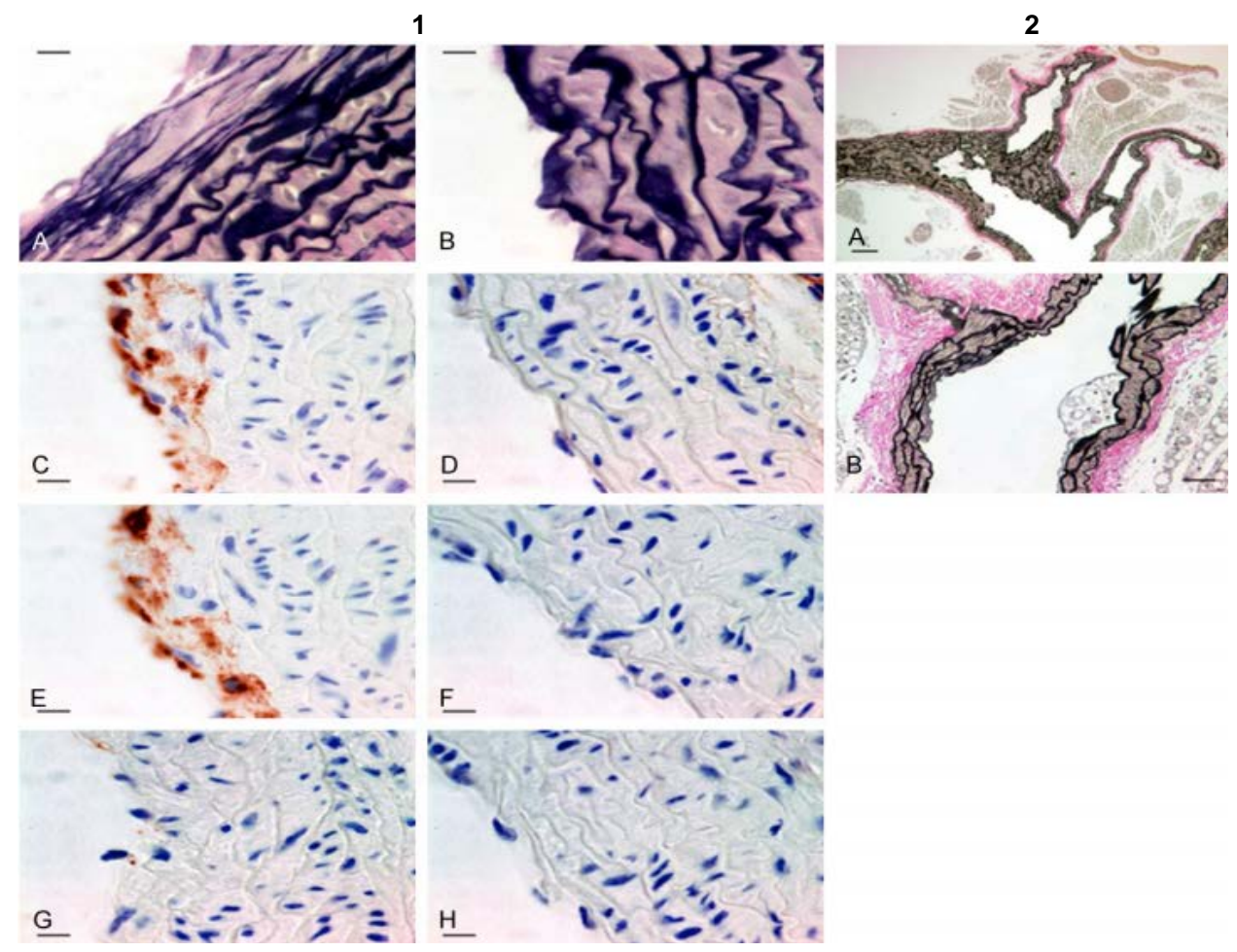

Figure 1. Ascorbate deprivation promotes the deposition of $\mathrm{Lp}(\mathrm{a})$ in the vascular wall. $1 \mathrm{Immu}-$ nostains of the aortic root sections from female $\mathrm{Gulo}^{-/-}$; $\mathrm{Lp}(\mathrm{a})+$ mice after 6 weeks of ascorbate deprivation (A), (C), (E), (G) and under supplementation with $2.75 \mathrm{mg}$ of ascorbate daily (B), (D), (F), (H). (A) and (B)-Elastic Van Gieson staining, (C) and (D) immunostaining for human apo(a), (E) and (F) immunostaining for human apoB-100 and (G) and (H) for fibrinogen, Scale bare $=10 \mu \mathrm{m}$. 2 Elastic Van Gieson stain of an atherosclerotic plaque formed in the cervical branches of the left subclavian artery shown in low and high magnification (2(A) and 2(B)). The picture was taken from the artery of a 10 month old female $\mathrm{Gulo}^{-1-} ; \mathrm{Lp}(\mathrm{a})+$ monse after 12 weeks on a low ascorbate diet $(0.15 \mathrm{mg} / \mathrm{dL}) .2(\mathrm{~A}):$ Scale Bar $=200 \mu \mathrm{m} .2(\mathrm{~B}):$ Scale Bar $=50 \mu \mathrm{m}$.

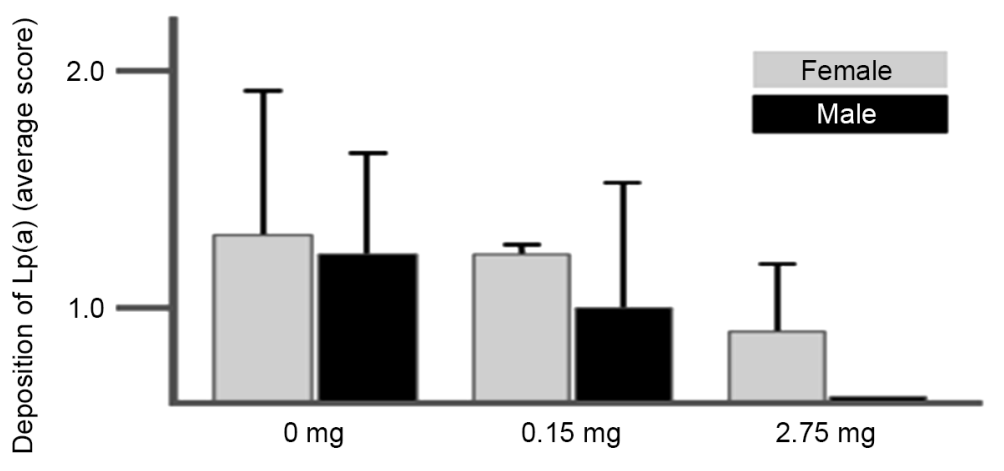

Daily ascorbate supplementation

Figure 2. Extent of $\mathrm{Lp}(\mathrm{a})$ deposition in vascular wall is inversely related to dietary ascorbate. The quantitative evaluation of histological immunostains for apo(a) and apoB-100 in the vascular wall is expressed as a score value calculated by multiplying the immunostained area by its intensity. The proximal, ascending, descending and thoracic part of the aorta was examined, including its branching vessels. Only areas in which apo(a) and apoB-100 were co-localized and formed clear deposits were included. A "O" score represents no deposits, “1" minimal deposit(s), "2" moderate deposit(s), and a score of " 3 " represents extensive $\operatorname{deposit}(\mathrm{s})$. 
Question 1: Why cholesterol deposits are formed in the arteries and not at the veins while the same cholesterol level circulates in the arteries and veins?

Question 2: Why coronary sclerosis is the most frequent form of atherosclerosis? In about 60 miles long human vascular system the cholesterol deposits are predominantly found in the coronary arteries, of a total length of a few inches.

Question 3: Why atherosclerosis is characteristic for humans while it is practically unknown in animal world, except of a few species that are not able to produce vitamin $\mathrm{C}$ internally (i.e. subhuman primates and guinea pigs)? The scientific enquiry into atherosclerosis and the cholesterol theory of CHD seems to have slowed down after the discovery and application of the cholesterol-lowering HMGCo-reductase inhibitors, statins, in the late 1980s. Large-scaled statin trials have demonstrated reduced cholesterol levels by an average of $40 \mathrm{mg} / \mathrm{mL}$ and reduced major vascular events by $20 \%$ [1]. The basis of this, Steinberg argued, proves the lipid hypothesis. However, several trials failed to prove the cholesterol lowering by statins resulted in reduction of myocardial infarction and cardiovascular events.

Gaps and major questions that remain unanswered in the lipid hypothesis of atherosclerosis could be answered by Rath and Pauling concept [60] and their unified theory of human cardiovascular disease [69]. They explain that the weakening of the vascular collagen matrix at the sites of high hemodynamic stress, which happens at coronary arteries, is the causative risk factors of CVD. This eventually leads to the weakening of collagen matrix and expansion of endothelial gaps allowing for an influx of large molecules Lp(a) and LDL as repair factors for vascular wall. The most frequent cause of the weakening of the vascular wall structure is chronic deficiency of vitamin $\mathrm{C}$ and consequently inadequate collagen synthesis. Finally, the sequel of $\mathrm{CHD}$, myocardial infarction, and heart failure become self-evident. Understanding this mechanism may guide the natural prevention of this disease and form the basis for developing effective therapeutic strategies aiming at natural reversal of atherosclerosis through the reinforcement of the vascular wall structure as its primary goal.

With the publication of the recent experimental study on the effects of vitamin C on Lp(a) in transgenic mice [77], it now remains for clinical trials with more rigorous design to follow through.

\section{Acknowledgements}

We acknowledge the editorial expertise of Dr. Bilwa Bhanap, and proofreading assistance of Ms. Cathy Flowers.

\section{References}

[1] Steinberg, D. (2007) The Cholesterol Wars: The Skeptics vs the Preponderance of Evidence. Elsevier, Oxford.

[2] Ross, R. (1999) Atherosclerosis-An Inflammatory Disease. New England Journal of Medicine, 340, 115-126. http://dx.doi.org/10.1016/s0002-8703(99)70266-8

[3] Benditt, E.P. and Benditt, J.M. (1973) Evidence for a Monoclonal Origin of Human Atherosclerotic Plaques. Proceedings of the National Academy of Sciences of the USA, 70, 1753- 
1756. http://dx.doi.org/10.1073/pnas.70.6.1753

[4] Harcombe, Z., Baker, J.S., Cooper, S.M., Davies, B., Sculthorpe, N., Di Nicolantonio, J.J. and Grace, F. (2015) Evidence from Randomised Controlled Trials Did Not Support the Introduction of Dietary Fat Guidelines in 1977 and 1983: A Systematic Review and Meta-Analysis. Open Heart, 2, e000196. http://dx.doi.org/10.1136/openhrt-2014-000196

[5] WHO (2014) Cardiovascular Diseases (CVDs). http://www.who.int/mediacentre/factsheets/fs317/en/

[6] Steinberg, D. (2004) Thematic Review Series: The Pathogenesis of Atherosclerosis. An Interpretive History of the Cholesterol Controversy: Part I. Journal of Lipid Research, 45, 1583-1593. http://dx.doi.org/10.1194/jlr.R400003-JLR200

[7] Konstantinov, I.E., Mejevoi, N., Anichkov, N.M. and Nikolai, N. (2006) Anichkov and His Theory of Atherosclerosis. Texas Heart Institute Journal, 33, 417-423.

[8] Anichkov, N.N. (1933) Experimental Arteriosclerosis in Animals. In: Cowdry, E.V., Ed., Ateriosclerosis: A Survey of the Problem, McMillan, New York, 271-322.

[9] Gofman, J.W. and Lindgren, F. (1950) The Role of Lipids and Lipoproteins in Atherosclerosis. Science, 111, 166-171. http://dx.doi.org/10.1126/science.111.2877.166

[10] Smith, E.B. and Slater, R.S. (1972) Relationship between Low-Density Lipoprotein in Aortic Intima and Serum-Lipid Levels. Lancet, 1, 463-469. http://dx.doi.org/10.1016/S0140-6736(72)90122-5

[11] Hoff, H.F., Karagas, M., Heideman, C.L., Gaubatz, J.W. and Gotto Jr., A.M. (1979) Correlation in the Human Aorta of APO B Fractions with Tissue Cholesterol and Collagen Content. Atherosclerosis, 32, 259-268. http://dx.doi.org/10.1016/0021-9150(79)90169-2

[12] Goldstein, J.L. and Brown, M.S. (1977) The Low-Density Lipoprotein Pathway and Its Relation to Atherosclerosis. Annual Review of Biochemistry, 46, 897-930. http://dx.doi.org/10.1146/annurev.bi.46.070177.004341

[13] Goldstein, J.L., Ho, Y.K., Basu, S.K. and Brown, M.S. (1979) Binding Site on Macrophages That Mediates Uptake and Degradation of Acetylated Low-Density Lipoprotein, Producing Massive Cholesterol Deposition. Proceedings of the National Academy of Sciences of the USA, 76, 333-337. http://dx.doi.org/10.1073/pnas.76.1.333

[14] Henriksen, T., Mahoney, E.M. and Steinberg, D. (1981) Enhanced Macrophage Degradation of Low Density Lipoprotein Previously Incubated with Cultured Endothelial Cells: Recognition by Receptors for Acetylated Low Density Lipoproteins. Proceedings of the National Academy of Sciences of the USA, 78, 6499-6503. http://dx.doi.org/10.1073/pnas.78.10.6499

[15] Hessler, J.R., Morel, D.W., Lewis, L.J. and Chisolm, G.M. (1983) Lipoprotein Oxidation and Lipoprotein-Induced Cytotoxicity. Arteriosclerosis, 3, 215-222. http://dx.doi.org/10.1161/01.ATV.3.3.215

[16] Steinbrecher, U.P., Parthasarathy, S., Leake, D.S., Witztum, J.L. and Steinberg, D. (1984) Modification of Low Density Lipoprotein by Endothelial Cells Involves Lipid Peroxidation and Degradation of Low Density Lipoprotein Phospholipids. Proceedings of the National Academy of Sciences of the United States of America, 81, 3883-3887. http://dx.doi.org/10.1073/pnas.81.12.3883

[17] Keys, A. (1995) Mediterranean Diet and Public Health: Personal Reflections. The American Journal of Clinical Nutrition, 61, 1321S-1323S.

[18] Keys, A. (1953) Atherosclerosis: A Problem in Newer Public Health. Journal of the Mount Sinai Hospital New York, 20, 118-139.

[19] Keys, A. (1980) Wine, Garlic, and CHD in Seven Countries. The Lancet, 315, 145-146. 
http://dx.doi.org/10.1016/S0140-6736(80)90620-0

[20] Francis, A.A. and Pierce, G.N. (2011) An Integrated Approach for the Mechanisms Responsible for Atherosclerotic Plaque Regression. Experimental and Clinical Cardiology, 16, 77-86.

[21] Enos, W.F., Holmes, R.H. and Beyer, J. (1953) Coronary Disease among United States Soldiers Killed in Action in Korea: Preliminary Report. JAMA, 152, 1090-1993. http://dx.doi.org/10.1001/jama.1953.03690120006002

[22] McNamara, J.J., Molot, M.A., Stremple, J.F. and Cutting, R.T. (1971) Coronary Artery Disease in Combat Casualties in Vietnam. JAMA, 216, 1185-1157. http://dx.doi.org/10.1001/jama.1971.03180330061012

[23] Sharpe, N. (2006) Cardiovascular Risk: A Paradigm Shift and New Global Challenge for Health Professionals. Acta Cardiologica Sinica, 22, 1-7.

[24] Steinberg, D. (2009) The LDL Modification Hypothesis of Atherosclerosis: An Update. Journal of Lipid Research, 50, S376-S381. http://dx.doi.org/10.1194/jlr.R800087-JLR200

[25] Steinberg, D. (2007) The Cholesterol Wars: The Skeptics vs. the Preponderance of Evidence. Elsevier, San Diego.

[26] Heinecke, J.W. (2003) Clinical Trials of Vitamin E in Coronary Artery Disease: Is It Time to Reconsider the Low-Density Lipoprotein Oxidation Hypothesis? Current Atherosclerosis Reports, 5, 83-87. http://dx.doi.org/10.1007/s11883-003-0075-1

[27] Steinberg, D. and Witztum, J.L. (2002) Is the Oxidative Modification Hypothesis Relevant to Human Atherosclerosis? Do the Antioxidant Trials Conducted to Date Refute the Hypothesis? Circulation, 105, 2107-2111. http://dx.doi.org/10.1161/01.CIR.0000014762.06201.06

[28] Kushi, L.H., Folsom, A.R., Prineas, R.J., Mink, P.J., Wu, Y. and Bostick, R.M. (1996) Dietary Antioxidant Vitamins and Death from Coronary Heart Disease in Postmenopausal Women. The New England Journal of Medicine, 334, 1156-1162. http://dx.doi.org/10.1056/NEJM199605023341803

[29] Vivekananthan, D.P., Penn, M.S., Sapp, S.K., Hsu, A. and Topol, E.J. (2003) Use of Antioxidant Vitamins for the Prevention of Cardiovascular Disease: Meta-Analysis of Randomised Trials. The Lancet, 361, 2017-2023. http://dx.doi.org/10.1016/S0140-6736(03)13637-9

[30] Boaz, M., Smetana, S., Weinstein, T., Matas, Z., Gafter, U., Iaina, A., Knecht, A., Weissgarten, Y., Brunner, D., Fainaru, M. and Green, M.S. (2000) Secondary Prevention with Antioxidants of Cardiovascular Disease in Endstage Renal Disease (SPACE): Randomised Placebo-Controlled Trial. The Lancet, 356, 1213-1218. http://dx.doi.org/10.1016/S0140-6736(00)02783-5

[31] Salonen, J.T., Nyyssönen, K., Salonen, R., Lakka, H.M., Kaikkonen, J., Porkkala-Sarataho, E., Voutilainen, S., Lakka, T.A., Rissanen, T., Leskinen, L., Tuomainen, T.P., Valkonen, V.P., Ristonmaa, U. and Poulsen, H.E. (2000) Antioxidant Supplementation in Atherosclerosis Prevention (ASAP) Study: A Randomized Trial of the Effect of Vitamins E and C on 3-Year Progression of Carotid Atherosclerosis. Journal of Internal Medicine, 248, 377-386. http://dx.doi.org/10.1046/j.1365-2796.2000.00752.x

[32] Stephens, N.G., Parsons, A., Schofield, P.M., Kelly, F., Cheeseman, K. and Mitchinson, M.J. (1996) Randomised Controlled Trial of Vitamin E in Patients with Coronary Disease: Cambridge Heart Antioxidant Study (CHAOS). The Lancet, 347, 781-786. http://dx.doi.org/10.1016/S0140-6736(96)90866-1

[33] Fang, J.C., Kinlay, S., Beltrame, J., Hikiti, H., Wainstein, M., Behrendt, D., Suh, J., Frei, B., 
Mudge, G.H., Selwyn, A.P. and Ganz, P. (2002) Effect of Vitamins C and E on Progression of Transplant-Associated Arteriosclerosis: A Randomised Trial. The Lancet, 359, 11081113. http://dx.doi.org/10.1016/S0140-6736(02)08154-0

[34] Paterson, J.C. (1940) Capillary Rupture with Intimal Haemorrhage in the Causation of Cerebral Vascular Lesions. Archives of Pathology, 29, 345-354.

[35] Paterson, J.C. (1941) Some Factors in the Causation of Intimal Haemorrhages and in the Precipitation of Coronary Thrombi. Canadian Medical Association Journal, 44, 114-120.

[36] Willis, G.C. (1953) An Experimental Study of Intimal Ground Substance in Atherosclerosis. Canadian Medical Association Journal, 69, 17-22.

[37] Willis, G.C. (1957) The Reversibility of Atherosclerosis. Canadian Medical Association Journal, 77, 106-108.

[38] Willis, G.C., Light, A.W. and Gow, W.S. (1954) Serial Arteriography in Atherosclerosis. Canadian Medical Association Journal, 71, 562-568.

[39] Spittle, C.R. (1971) Atherosclerosis and Vitamin C. The Lancet, 298, 1280-1281. http://dx.doi.org/10.1016/S0140-6736(71)90601-5

[40] Holloway, D.E., Peterson, F.J., Prigge, W.F. and Gebhard, R.L. (1981) Influence of Dietary Ascorbic Acid upon Enzymes of Sterol Biosynthesis in Guinea Pig. Biochemical and Biophysical Research Communications, 102, 1283-1289. http://dx.doi.org/10.1016/S0006-291X(81)80150-7

[41] Greene, Y.J., Harwood Jr., H.J. and Stacpoole, P.W. (1985) Ascorbic Acid Regulation of 3-Hydroxy-3-Methylglutaryl Coenzyme A Reductase Activity and Cholesterol Synthesis in Guinea Pig Liver. Biochimica et Biophysica Acta (BBA)-Lipids and Lipid Metabolism, 834, 134-138. http://dx.doi.org/10.1016/0005-2760(85)90186-9

[42] Harwood Jr., H.J., Greene, Y.J. and Stacpoole, P.W. (1986) Inhibition of Human Leukocyte 3-Hydroxy-3-Methylglutaryl Coenzyme A Reductase Activity by Ascorbic Acid. An Effect Mediated by the Free Radical Monodehydroascorbate. The Journal of Biological Chemistry, 261, 7127-1735.

[43] Albers, J.J., Marcovina, S.M. and Lodge, M.S. (1990) The Unique Lipoprotein(a): Properties and Immunochemical Measurement. Clinical Chemistry, 36, 2019-2026.

[44] Blumberg, B.S., Bernanke, D. and Allison, A.C. (1962) A Human Lipoprotein Polymorphism. Journal of Clinical Investigation, 41, 1936-1944. http://dx.doi.org/10.1172/JCI104651

[45] Berg, K. (1963) A New Serum Type System in Man-The L System. Acta Pathologica Microbiologica Scandinavica, 59, 369-382. http://dx.doi.org/10.1111/j.1699-0463.1963.tb01808.x

[46] Fortmann, S.P. and Marcovina, S.M. (1997) Lipoprotein(a), a Clinically Elusive Lipoprotein Particle. Circulation, 95, 295-296. http://dx.doi.org/10.1161/01.CIR.95.2.295

[47] Kiechi, S. and Willeit, J. (2010) The Mysteries of Lipoprotein(a) and Cardiovascular Disease Revisited. Journal of American College of Cardiology, 55, 2168-2170.

[48] Eaton, D.L., Fless, G.M., Kohr, W.J., McLean, J.W., Xu, Q.T., Miller, C.G., Lawn, R.M. and Scanu, A.M. (1987) Partial Amino Acid Sequence of Apolipoprotein(a) Shows That It Is Homologous to Plasminogen. Proceedings of the National Academy of Sciences of the United States of America, 84, 3224-3228. http://dx.doi.org/10.1073/pnas.84.10.3224

[49] Kratzin, H., Armstrong, V.W., Niehaus, M., Hilschmann, N. and Seidel, D. (1987) Structural Relationship of an Apolipoprotein (a) Phenotype (570 kDa) to Plasminogen: Homologous Kringle Domains Are Linked by Carbohydrate-Rich Regions. Biological Chemistry Hoppe-Seyler, 368, 1533-1544. http://dx.doi.org/10.1515/bchm3.1987.368.2.1533 
[50] McLean, J.W., Tomlinson, J.E., Kuang, W.J., Eaton, D.L., Chen, E.Y., Fless, G.M., Scanu, A.M. and Lawn, R.M. (1987) cDNA Sequence of Human Apolipoprotein(a) Is Homologous to Plasminogen. Nature, 330, 132-137. http://dx.doi.org/10.1038/330132a0

[51] Schriewer, H., Assmann, G., Sandkamp, M. and Schulte, H. (1984) The Relationship of Lipoprotein (a) $(\mathrm{Lp}(\mathrm{a}))$ to Risk Factors of Coronary Heart Disease: Initial Results of the Prospective Epidemiological Study on Company Employees in Westfalia. Journal of Clinical Chemistry \& Clinical Biochemistry, 22, 591-596.

http://dx.doi.org/10.1515/cclm.1984.22.9.591

[52] Dahlen, G.H., Guyton, J.R., Attar, M., Farmer, J.A., Kautz, J.A. and Gotto Jr., A.M. (1986) Association of Levels of Lipoprotein Lp(a), Plasma Lipids, and Other Lipoproteins with Coronary Artery Disease Documented by Angiography. Circulation, 74, 758-765. http://dx.doi.org/10.1161/01.CIR.74.4.758

[53] Armstrong, V.W., Cremer, P., Eberle, E., Manke, A., Schulze, F., Wieland, H., Kreuzer, H. and Seidel, D. (1986) The Association between Serum Lp(a) Concentrations and Angiographically Assessed Coronary Atherosclerosis. Dependence on Serum LDL Levels. Atherosclerosis, 62, 249-257. http://dx.doi.org/10.1016/0021-9150(86)90099-7

[54] Walton, K.W., Hitchens, J., Magnani, H.N. and Khan, M. (1974) A Study of Methods of Identification and Estimation of LP(a) Lipoprotein and of Its Significance in Health, Hyperlipidaemia and Atherosclerosis. Atherosclerosis, 20, 323-346.

http://dx.doi.org/10.1016/0021-9150(74)90016-1

[55] Rath, M. (2003) Why Animals Don't Get Heart Attacks...but People Do! Dr Rath Education Services USA, BV, Santa Clara.

[56] Rath, M., Niendorf, A., Reblin, T., Dietel, M., Krebber, H.J. and Beisiegel, U. (1989) Detection and Quantification of Lipoprotein(a) in the Arterial Wall of 107 Coronary Bypass Patients. Arteriosclerosis, 9, 579-592. http://dx.doi.org/10.1161/01.ATV.9.5.579

[57] Niendorf, A., Rath, M., Wolf, K., Peters, S., Arps, H., Beisiegel, U. and Dietel, M. (1990) Morphological Detection and Quantification of Lipoprotein(a) Deposition in Atheromatous Lesions of Human Aorta and Coronary Arteries. Virchows Archiv A, 417, 105-111. http://dx.doi.org/10.1007/BF02190527

[58] Beisiegel, U., Niendorf, A., Wolf, K., Reblin, T. and Rath, M. (1990) Lipoprotein(a) in the Arterial Wall. European Heart Journal, 11, 174-183. http://dx.doi.org/10.1093/eurheartj/11.suppl_E.174

[59] Hajjar, K.A., Gavish, D., Breslow, J.L. and Nachman, R.L. (1989) Lipoprotein(a) Modulation of Endothelial Cell Surface Fibrinolysis and Its Potential Role in Atherosclerosis. Nature, 339, 303-305. http://dx.doi.org/10.1038/339303a0

[60] Rath, M. and Pauling, L. (1990) Hypothesis: Lipoprotein(a) Is a Surrogate for Ascorbate. Proceedings of the National Academy of Sciences of the United States of America, 87, 62046207. http://dx.doi.org/10.1073/pnas.87.16.6204

[61] Rath, M. and Pauling, L. (1990) Immunological Evidence for the Accumulation of Lipoprotein(a) in the Atherosclerotic Lesion of the Hypoascorbemic Guinea Pig. Proceedings of the National Academy of Sciences of the United States of America, 87, 9388-9390. http://dx.doi.org/10.1073/pnas.87.23.9388

[62] Rath, M. and Pauling, L. (1991) Solution to the Puzzle of Human Cardiovascular Disease: Its Primary Cause Is Ascorbate Deficiency, Leading to the Deposition of Lipoprotein(a) and Fibrinogen/Fibrin in the Vascular Wall. Journal of Orthomolecular Medicine, 6, 125-134.

[63] Brown, M.S. and Goldstein, J.L. (1984) How LDL Receptors Influence Cholesterol and Atherosclerosis. Scientific American, 251, 58-66. 
http://dx.doi.org/10.1038/scientificamerican1184-58

[64] Ross, R. (1986) The Pathogenesis of Atherosclerosis-An Update. The New England Journal of Medicine, 314, 488-500. http://dx.doi.org/10.1056/NEJM198602203140806

[65] Parthasarathy, S., Carew, T.E., Khoo, J.C. and Witztum, J.L. (1989) Beyond Cholesterol. Modifications of Low-Density Lipoprotein That Increase Its Atherogenicity. The New England Journal of Medicine, 320, 915-924.

[66] Ruoslahti, E. and Pierschbacher, M.D. (1987) New Perspectives in Cell Adhesion: RGD and Integrins. Science, 238, 491-497. http://dx.doi.org/10.1126/science.2821619

[67] Rath, M. and Pauling, L. (1991) Apoprotein(a) Is an Adhesive Protein. Journal of Orthomolecular Medicine, 6, 139-143.

[68] Stenman, S., von Smitten, K. and Vaheri, A. (1980) Fibronectin and Atherosclerosis. Acta Medica Scandinavica, 208, 165-170. http://dx.doi.org/10.1111/j.0954-6820.1980.tb10949.x

[69] Rath, M. and Pauling, L. (1992) Unified Theory of Human Cardiovascular Disease Leading the Way to the Abolition of This Disease as a Cause for Human Mortality. Journal of Orthomolecular Medicine, 6, 139-143.

[70] Rath, M. and Pauling, L. (1992) Plasmin-Induced Proteolysis and the Role of Apoprotein(a), Lysine, and Synthetic Lysine Analogs. Journal of Orthomolecular Medicine, 7, 17-23.

[71] Rath, M. (1992) Reducing the Risk for Cardiovascular Disease with Nutritional Supplements. Journal of Orthomolecular Medicine, 7, 153-162.

[72] Maeda, N., Hagihara, H., Nakata, Y., Hiller, S., Wilder, J. and Reddick, R. (2000) Aortic Wall Damage in Mice Unable to Synthesize Ascorbic Acid. Proceedings of the National Academy of Sciences of the United States of America, 97, 841-846. http://dx.doi.org/10.1073/pnas.97.2.841

[73] Ivanov, V., Ivanova, S.V. and Niedzwiecki, A. (1997) Ascorbate Affects Proliferation of Guinea-Pig Vascular Smooth Muscle Cells by Direct and Extracellular Matrix-Mediated Effects. Journal of Molecular and Cellular Cardiology, 29, 3293-3303. http://dx.doi.org/10.1006/jmcc.1997.0555

[74] Munrad, S., Grove, D., Lindberg, K.A., Reynolds, G., Sivarajah, A. and Pinnell, S.R. (1981) Regulation of Collagen Synthesis by Ascorbic Acid. Proceedings of the National Academy of Sciences of the United States of America, 78, 2879-2882. http://dx.doi.org/10.1073/pnas.78.5.2879

[75] Ivanov, V., Ivanova, S., Kalinovsky, T., Niedzwiecki, A. and Rath, M. (2008) Plant-Derived Micronutrients Suppress Monocyte Adhesion to Cultured Human Aortic Endothelial Cell Layer by Modulating Its Extracellular Matrix Composition. Journal of Cardiovascular Pharmacology, 52, 55-65. http://dx.doi.org/10.1097/FJC.0b013e31817e692f

[76] Rath, M. and Niedzwiecki, A. (1996) Nutritional Supplement Program Halts Progression of Early Coronary Atherosclerosis Documented by Ultrafast Computed Tomography. Journal of Applied Nutrition, 48, 67-78.

[77] Cha, J., Niedzwiecki, A. and Rath, M. (2015) Hypoascorbemia Induces Atherosclerosis and Vascular Deposition of Lipoprotein(a) in Trangenic Mice. American Journal of Cardiovascular Disease, 5, 53-62. 
Submit or recommend next manuscript to SCIRP and we will provide best service for you:

Accepting pre-submission inquiries through Email, Facebook, LinkedIn, Twitter, etc. A wide selection of journals (inclusive of 9 subjects, more than 200 journals)

Providing 24-hour high-quality service

User-friendly online submission system

Fair and swift peer-review system

Efficient typesetting and proofreading procedure

Display of the result of downloads and visits, as well as the number of cited articles

Maximum dissemination of your research work

Submit your manuscript at: http://papersubmission.scirp.org/

Or contactwjcd@scirp.org 